\title{
Comparison of culture with the polymerase chain reaction for detection of Ureaplasma urealyticum in endotracheal aspirates of preterm infants
}

\author{
N. A. CUNLIFFE, S. FERGUSSON, F. DAVIDSON, A. LYON* and P. W. ROSS \\ Department of Medical Microbiology, University of Edinburgh, Medical School, Teviot Place, Edinburgh EH8 \\ $9 A G$ and *Department of Child Life and Health, University of Edinburgh, 17 Hatton Place, Edinburgh EH9 1 UW
}

\begin{abstract}
Polymerase chain reaction (PCR) amplification of the urease genes of Ureaplasma urealyticum was compared with culture for detection of the organism in 100 endotracheal aspirates from 54 ventilated preterm infants. Ninety specimens gave negative results by both culture and PCR and three specimens gave positive results by both culture and PCR. Six specimens were negative by culture but positive by PCR. The one specimen positive by culture and negative by PCR was interpreted as a false-positive culture result. Overall agreement between results obtained by culture and PCR was 93\%. PCR is a sensitive and reliable method for the detection of $U$. urealyticum in neonatal endotracheal secretions. Detection by PCR (1-2 days) is more rapid than culture (2-5 days) and this will be important if early therapeutic intervention is shown to be effective.
\end{abstract}

\section{Introduction}

Ureaplasma urealyticum is an important genital mycoplasma and is found in the cervix or vagina of $40-80 \%$ of sexually mature asymptomatic women [1]. It has been associated with various disease states including non-gonococcal urethritis, urethroprostatitis, epididymitis, urinary calculi, post-partum fever, chorioamnionitis, as well as being implicated in infertility [2]. Its role in prematurity and neonatal disease has also received considerable attention [1]. Lower respiratory tract infection with $U$. urealyticum in low birth weight infants has been shown to be significantly associated with acute and chronic lung disease [3-5].

The method most commonly used to detect $U$. urealyticum is culture; both liquid and solid media are used [6]. However, because the organisms are fragile and susceptible to adverse environmental conditions, culture may be difficult and can take up to 5 days. The polymerase chain reaction (PCR) has had a major impact on the diagnosis of many infectious diseases [7] but, as yet, there have been few reports on its use for the detection of $U$. urealyticum in clinical samples [8-10].

Received 29 Aug. 1995; revised version accepted 4 Dec. 1995.

Corresponding author: Dr N. A. Cunliffe.
As part of a prospective intervention study to assess the role of genital mycoplasmas in the development of chronic lung disease in preterm infants and the effect on this of early treatment with erythromycin, the PCR technique was compared with culture for the detection of $U$. urealyticum in neonatal endotracheal secretions.

\section{Materials and methods}

\section{Samples}

One hundred endotracheal aspirates, obtained from 54 ventilated preterm infants by lavage with saline $0.9 \%$, were placed in sterile containers, delivered promptly to the microbiology laboratory and cultured. Any remaining aspirate was stored at $-20^{\circ} \mathrm{C}$ until analysed by PCR.

\section{Culture}

Endotracheal aspirates were cultured in Unipath Ureaplasma Broth (Unipath Ltd, Wade Road, Basingstoke, Hampshire). Urea supplement was added to the broth which was then dispensed aseptically in $1.8 \mathrm{ml}$ volumes. Aspirate $(0.2 \mathrm{ml})$ was added, the solution was mixed and the pipette tip was discarded. With a fresh tip, $0.2 \mathrm{ml}$ was removed, added to a second tube and again mixed. The process was repeated until five tubes were inoculated to give a range of sample dilutions from one in $10^{1}$ to one in $10^{5}$. U. urealyticum possesses a urease that breaks down urea to ammonia. This raises 
the $\mathrm{pH}$ of the broth, resulting in a colour change from yellow to red with the indicator phenol red. All tubes were incubated aerobically at $37^{\circ} \mathrm{C}$ for up to 5 days, and examined daily for a colour change. All tubes that showed a colour change were subcultured on to blood agar and incubated aerobically to exclude bacterial contamination. If growth occurred on subculture, the organism was inoculated into fresh Ureaplasma broth and again incubated aerobically to check for urease activity. If no growth occurred on subculture or if the isolate did not demonstrate urease activity, the colour change was ascribed to $U$. urealyticum. Growth of $U$. urealyticum is reported in colour-changing units $/ \mathrm{ml}$ $(\mathrm{ccu} / \mathrm{ml})$. If only the first tube changes colour, this indicates the presence of $10 \mathrm{ccu} U$. urealyticum $/ \mathrm{ml}$; colour changes in tubes $2-5$ indicate $100,1000,10000$ and $100000 \mathrm{ccu}$ of $U$. urealyticum $/ \mathrm{ml}$, respectively.

\section{DNA extraction}

Nucleic acid was extracted from $100 \mu 1$ of endotracheal aspirate; $100 \mu \mathrm{l}$ of Ureaplasma broth was similarly extracted in the investigation of a single false-positive culture result. The method used was a modification of that described by Jarvis et al. [11]. A solution of TNE buffer containing $0.11 \mathrm{M} \mathrm{NaCl}, 55 \mathrm{mM}$ Tris, $\mathrm{pH} 8.0$, and $1.1 \mathrm{~mm}$ EDTA, pH 8.0, was mixed with SDS $0.55 \%$, proteinase $\mathrm{K} 1 \mathrm{mg} / \mathrm{ml}$ and poly-adenylic acid (Poly-A) $40 \mu \mathrm{g} / \mathrm{ml}$. The mixture was incubated at $37^{\circ} \mathrm{C}$ for $10 \mathrm{~min}$ to inactivate any endogenous RNAases. The sample was added directly to $400 \mu$ l of this solution and the tubes were vortex mixed thoroughly. Samples were incubated at $37^{\circ} \mathrm{C}$ for $90 \mathrm{~min}$. Nucleic acid was extracted by addition of $450 \mu \mathrm{l}$ of phenol and then centrifugation for $10 \mathrm{~min}$ at $18000 \mathrm{~g}$ after thorough mixing. The aqueous phase was removed into $450 \mu \mathrm{l}$ of chloroform: isoamylalcohol (50:1), mixed and centrifuged as before. Nucleic acid was precipitated by addition of $2.5 \mathrm{vol}$ of ethanol $100 \%$ and $40 \mu \mathrm{l}$ of $3 \mathrm{M}$ sodium acetate, $\mathrm{pH}$ 5.2. The solution was mixed and nucleic acids were precipitated overnight at $-20^{\circ} \mathrm{C}$. Nucleic acid was pelleted by centrifugation at $18000 \mathrm{~g}$ for $15 \mathrm{~min}$, the pellet was washed once with ethanol $80 \%$ and dried before resuspending in $25 \mu \mathrm{l}$ of diethylpyrocarbonate-treated distilled water. The sample was heated to $60^{\circ} \mathrm{C}$ for $10 \mathrm{~min}$ to aid solubilisation of the nucleic acid before use in the PCR.

\section{PCR}

The oligonucleotide primers used, based on the urease structural genes of $U$. urealyticum, have been shown previously to be highly specific for $U$. urealyticum and, under optimal conditions, to allow detection of $<10 \mathrm{cfu}$ of each serotype of the organism [9]. The primers used were 5'-CAATCTGCTCGTGAAGTATTAC-3' (sense) and 5'-ACGACGTCCATAAGCAACT$3^{\prime}$ (antisense). A positive control ( $U$. urealyticum serovar VIII) and a negative control (sterile water) were included in each PCR experiment.
The PCR mixture contained $10 \mu \mathrm{l}$ of DNA in a final reaction volume of $50 \mu \mathrm{l}$. The final concentrations of the reaction mixture were: $10 \mathrm{mM}$ Tris- $\mathrm{HC} 1, \mathrm{pH} 9.0$, $2.5 \mathrm{mM} \mathrm{MgCl}_{2}$, TritonX-100 1\%, $33 \mu \mathrm{M}$ each of dGTP, dATP, dCTP and dTTP, $0.5 \mu \mathrm{M}$ of each of the primers and Taq polymerase (Promega) 20 units $/ \mathrm{ml}$. Twentyfive heat cycles were used, each consisting of $0.6 \mathrm{~min}$ at $94^{\circ} \mathrm{C}, 0.7 \mathrm{~min}$ at $50^{\circ} \mathrm{C}$ and $3.0 \mathrm{~min}$ at $68^{\circ} \mathrm{C}$. The products of the reaction were sufficient to be visualised under UV light on an agarose $2 \%$ gel (Flowgen) stained with ethidium bromide (final concentration $0.5 \mu \mathrm{g} / \mathrm{ml}$ ).

\section{Results}

One hundred aspirates were analysed from 54 infants. Four $(4 \%)$ from four $(7.4 \%)$ infants were positive for $U$. urealyticum by culture and $96(96 \%)$ from 50 $(92.6 \%)$ infants gave negative results. Nine $(9 \%)$ from eight $(14.8 \%)$ infants were positive by PCR, and $91(91 \%)$ from $46(85.2 \%)$ infants gave negative results. There was agreement between results obtained by culture and PCR in 93 (93\%) aspirates; three aspirates (3\%) were positive by culture and PCR, and $90(90 \%)$ were negative by culture and PCR. Six aspirates $(6 \%)$ were negative by culture and positive by PCR. Of these, two aspirates were from infants who were receiving erythromycin. One aspirate $(1 \%)$ was positive by culture and negative by PCR; however, in this sample, PCR on the ureaplasma broth gave a negative result (Table 1).

\section{Discussion}

This study examined the sensitivity of detection of $U$. urealyticum in endotracheal aspirates of ventilated preterm infants by culture and PCR. Overall agreement between the results obtained by both methods was $93 \%$. Of the six specimens negative by culture but positive by PCR, two were aspirates taken from infants receiving erythromycin, an agent which is bacteriostatic for ureaplasmas [12]. This explains the negative culture in the presence of the positive PCR result, as the DNA of non-dividing organisms could still be detected. The other four culture-negative, PCR-positive aspirates may be explained by the greater sensitivity of PCR compared with culture. It has been stated that even

Table 1. Comparison of culture with PCR for the detection of $U$. urealyticum in endotracheal aspirates from preterm infants

\begin{tabular}{lccc}
\hline & \multicolumn{2}{c}{ Culture result } & \\
\cline { 2 - 3 } PCR result & Positive & Negative & Total \\
\hline Positive & 3 & 6 & 9 \\
Negative & 1 & 90 & 91 \\
Total & 4 & 96 & 100 \\
\hline
\end{tabular}


with the combined use of liquid and solid media, vaginal culture for $U$. urealyticum detects only $86 \%$ of positive samples [13]. No comparable sensitivity data exist for culture of $U$. urealyticum from neonatal endotracheal secretions. Preliminary experiments confirmed the sensitivity of PCR. Endotracheal aspirates were spiked with various concentrations of $U$. urealyticum, and $<10 \mathrm{ccu}$ could be consistently detected (data not shown). As ureaplasmas are fragile organisms it is possible that some organisms may have died after sample collection. Due to the very small volume of sample available it was not possible to confirm the six culture-negative, PCR-positive results by repeat assay. However, as each PCR positive sample gave a strong reaction and appropriate controls were included in each experiment, it is unlikely that the PCR results were erroneous. A single sample was positive by culture (at $10 \mathrm{ccu} / \mathrm{ml}$ ) but negative by PCR. As PCR of the culture broth was repeatedly negative it is likely that this result was a false positive by culture. This is a recognised feature of ureaplasma broths and may result from either lack of an air-tight seal to the glass vial or the presence of epithelial cells which may produce urease [14].

In two reports of PCR amplification of urease genes to detect $U$. urealyticum in endotracheal aspirates of neonates, Scheurlen et al. [8] detected $U$. urealyticum in one of 36 samples and Blanchard et al. [9], who examined 95 samples by culture and PCR, found that 11 of 12 samples positive by culture were also positive by PCR. The single sample in the study by Blanchard et al. which was positive by culture and negative by PCR, was shown to contain only a small number of organisms. There were no samples in their study that were negative by culture but positive by PCR. This may be partly explained by the use of a more sensitive culture technique in their study, as both liquid and solid media were used for isolation. Alternatively, PCR detection may have been more consistent in the current study. In the study by Blanchard et al., endotracheal aspirates were found to contain inhibitors of DNA amplification, thought to be polypeptides. The problem was overcome when a higher concentration of proteinase $\mathrm{K}(0.5 \mathrm{mg} / \mathrm{ml})$ was used in the lysis solution. Proteinase $\mathrm{K} 1 \mathrm{mg} / \mathrm{ml}$ was used throughout the present study. Finally, this study demonstrated that sufficient DNA can be obtained directly from the endotracheal aspirates without the need to centrifuge and resuspend the specimen as described previously $[8,9]$.

The primers used in this study do not differentiate the two biovars of $U$. urealyticum. It is known that PCR with the 16S-rRNA gene sequences distinguishes the T960 biovar from the parvo biovar [15], and we plan to apply these primers to positive isolates of $U$. urealyticum in future studies in an attempt to correlate these findings with the development of chronic lung disease in preterm infants. The relative contribution of the different biovars to disease may then emerge.
$U$. urealyticum is transmitted to the newborn baby from the mother's genital tract. We have found a vertical transmission rate of $37 \%$ in babies under 31 weeks gestation [16]. In approximately one-third of cases cultures were negative at birth and only subsequently became positive. Nosocomial infection has not been reported and is unlikely in the neonate [1]. These organisms may be difficult to detect by culture if they are in small numbers. In clinical practice it is common for very preterm babies to be treated with broad spectrum antibiotics and it is possible that the eradication of other organisms may encourage growth of $U$. urealyticum. The increased sensitivity of PCR would allow earlier detection of infection with $U$. urealyticum in these cases where initial culture is negative. Cassell et al. [1] have reviewed the large amount of evidence associating infection with $U$. urealyticum and lung disease in preterm infants. Infection with this organism is one of the many factors capable of inducing inflammation in the lungs of newborn babies, and it is the failure of the preterm infant to down-regulate this inflammatory response that is thought to be the mechanism of chronic lung damage $[17,18]$. If intervention studies aimed at eradicating the organism show any reduction in the severity of chronic lung disease, it will be important to detect infection as soon as possible after birth, if possible before the inflammatory response is established. PCR is not only a more sensitive and reliable means of detecting $U$. urealyticum but also the results can be available within a day, compared with 2-5 days for culture, allowing earlier treatment of the infected infants.

\section{References}

1. Cassell GH, Waites KB, Watson HL, Crouse DT, Harasawa R. Ureaplasma urealyticum intrauterine infection: role in prematurity and disease in newborns. Clin Microbiol Rev 1993; 6: 69-87.

2. Taylor-Robinson D. Ureaplasma urealyticum (T-strain Mycoplasma) and Mycoplasma hominis. In: Mandell G L, Bennett J E, Dolin R (eds) Mandell, Douglas and Bennett's Principles and practice of infectious diseases, 4th edn, vol 2. New York, Churchill Livingstone. 1995: 1713-1718.

3. Cassell GH, Waites KB, Crouse DT et al. Association of Ureaplasma urealyticum infection of the lower respiratory tract with chronic lung disease and death in very-low-birth-weight infants. Lancet 1988; 2: 240-245.

4. Payne NR, Steinberg SS, Ackerman P et al. New prospective studies of the association of Ureaplasma urealyticum colonization and chronic lung disease. Clin Infect Dis 1993; 17 Suppl 1: S117-S121.

5. Lyon AJ, McIntosh N, Iles R, Ross PW. Bacteria may contribute to lung disease in neonates. $B M J 1994 ; 308$ : 787.

6. Taylor-Robinson D. Genital mycoplasma infections. Clin Lab Med 1989; 9: 501-523.

7. Peter JB. The polymerase chain reaction: amplifying our options. Rev Infect Dis 1991; 13: 166-171.

8. Scheurlen W, Frauendienst G, Schrod L, von Stockhausen H-B. Polymerase chain reaction - amplification of urease genes: rapid screening for Ureaplasma urealyticum infection in endotracheal aspirates of ventilated newborns. Eur $J$ Pediatr 1992; 151: 740-742

9. Blanchard A, Hentschel J, Duffy L, Baldus K, Cassell GH. Detection of Ureaplasma urealyticum by polymerase chain reaction in the urogenital tract of adults, in amniotic fluid, and 
in the respiratory tract of newborns. Clin Infect Dis 1993; 17 Suppl 1: S148-S153.

10. Teng K, Li M, Yu W, Li H, Shen D, Liu D. Comparison of PCR with culture for detection of Ureaplasma urealyticum in clinical samples from patients with urogenital infections. $J$ Clin Microbiol 1994; 32: 2232-2234.

11. Jarvis LM, Watson HG, McOmish F, Peutherer JF, Ludlam CA, Simmonds, P. Frequent reinfection and reactivation of hepatitis $C$ virus genotypes in multitransfused hemophiliacs. $J$ Infect Dis 1994; 170: 1018-1022.

12. Waites KB, Crouse DT, Cassell GH. Therapeutic considerations for Ureaplasma urealyticum infections in neonates. Clin Infect Dis 1993; 17 Suppl 1: S208-S214.

13. McCormack WM, Rankin JS, Lee Y-H. Localization of genital mycoplasmas in women. Am J Obstet Gynecol 1972; 112: 920-923.

14. Taylor-Robinson D, Addey JP. Comparison of techniques for the isolation of T-strain mycoplasmas. Nature 1969; 222: 274 275.

15. Robertson JA, Vekris A, Bebear C, Stemke GW. Polymerase Chain Reaction using 16SrRNA gene sequences distinguishes the two biovars of Ureaplasma urealyticum. J Clin Microbiol 1993; 31: 824-830.

16. Iles $\mathrm{R}$, Lyon $\mathrm{AJ}$, Ross $\mathrm{P}$, McIntosh $\mathrm{N}$. Infection with Ureaplasma urealyticum and Mycoplasma hominis and the development of chronic lung disease in preterm infants. Acta Paediatr Scand 1996; 00: 000-000.

17. Rudd PT, Cassell GH, Waites KB, Duffy LB. Ureaplasma urealyticum pneumonia: experimental production and demonstration of age-related susceptibility. Infect Immun 1989; 57: 918-925.

18. McColm J, McIntosh $\mathrm{N}$. Interleukin-8 in bronchoalveolar lavage samples as a predictor of chronic lung disease in premature infants. Lancet 1994; 343: 729. 